\title{
22. STRATIGRAPHY AND SEDIMENTATION
}

\author{
H. E. Cook, University of California, Riverside
}

\section{INTRODUCTION}

The purposes of this section are twofold: first, to call attention to and present evidence for the application of classical North American stratigraphic principles to deep sea sediments; and second, to present a working stratigraphic model for the central and eastern equatorial Pacific deep sea sediments.

Because one person aboard Leg 9 described all the cores except those at one site, it was possible to maintain a high degree of uniformity in core description, identification of biogenous constituents, visual percentage estimates of constituents, and sediment classification.

All sediment names consist of three parts in the following order: (1) color, (2) biogenous and mineralogic constituents, and (3) degree of induration. For example, an unconsolidated very pale orange ooze made up of foraminifera, radiolarians, and calcareous nannofossils might be a very pale orange foraminiferal-radiolarian-calcareous nannofossil ooze. This classification scheme is illustrated in Figure 1. The terms ooze and chalk are used to designate different degrees of induration. Thus, the different degrees of increasing induration go from ooze to chalk ooze to ooze chalk to chalk.

Relative percentages of the major constituents were visually estimated from smear slides. Curves of accessory constituent abundance were constructed and are shown in the Site Reports of this volume.

\section{STRATIGRAPHIC NOMENCLATURE AND CONCEPTS}

The recovery of over 1500 meters of core at eight sites on Leg 9 presented a good opportunity to attempt the application of classical stratigraphic concepts to deep marine sediments of the equatorial Pacific. We continuously cored Site 77 where we recovered about 480 meters of sediment. This site was divided into several stratigraphic units which serve as a standard of reference for comparison with Leg 9 and Leg 8 sites. All eight equatorial sites were cored to basement.

The fundamental lithologic unit for deciphering the stratigraphic history of an area is the formation. The most useful and objective criterion to distinguish the stratigraphic units in the equatorial Pacific is color and to a lesser degree bedding characteristics. A wide spectrum of colors, including white (N9), dusky brown (5YR $2 / 2$ ), dusky green (5G $3 / 2$ ), very dusky purple (5 2/2), and various shades in between, is present in these sediments. Color variations are often accompanied by textural, mineralogic, and biotic changes which further aids in the characterization of these formations. Thus, color, in conjunction with bedding characteristics and stratigraphic sequence, served to define formations and make lithologic correlations.

A cooperative examination of logs and color strip photographs of Leg 8 and Leg 9 cores was made by Jon Galehouse of Leg 8 and H.E. Cook of Leg 9 in order to develop a uniform nomenclature for the equatorial $\mathrm{Pa}$ cific. In naming formations Legs 8 and 9 follow the code of the American Commission on Stratigraphic Nomenclature (1961) rather than the recommendation of J. Andrews and K.J. Hsu (1970). The units are designied at oceanic geologic formations, using the drill sites as type sections and applying names of nearby islands and submarine fracture zones. Even though the drill sites are 200 to 1200 kilometers apart, the consistent stratigraphic sequence and areal distribution of these lithologic units at Leg 8 and Leg 9 sites led us to define four oceanic formations. Three of these oceanic formations, the Clipperton, Marquesas, and Line Islands were defined by Leg 8 scientists (Sutton et al., 1971). Leg 9 names one new formation, the San Blas Oceanic Formation, which is recognized at Sites 81 through 84 and is lithologically distinct from its stratigraphic equivalents in Sites 77 through 80 . These formations and their depths below the sea floor are listed in Table 1 and diagrammatically illustrated in Figure 2, which is a composite stratigraphic section of the equatorial Pacific formations used by Leg 9. Plate 1, which is a fence diagram (in pocket attached to inside back cover), illustrates the basic stratigraphic framework and attempts to show in a generalized way how color served for establishing and correlating rock stratigraphic units. This fence diagram was constructed by placing the top of each section at the geographic position of the site. Table 2 summarizes the diagnostic characteristics used to define and recognize these formations. 


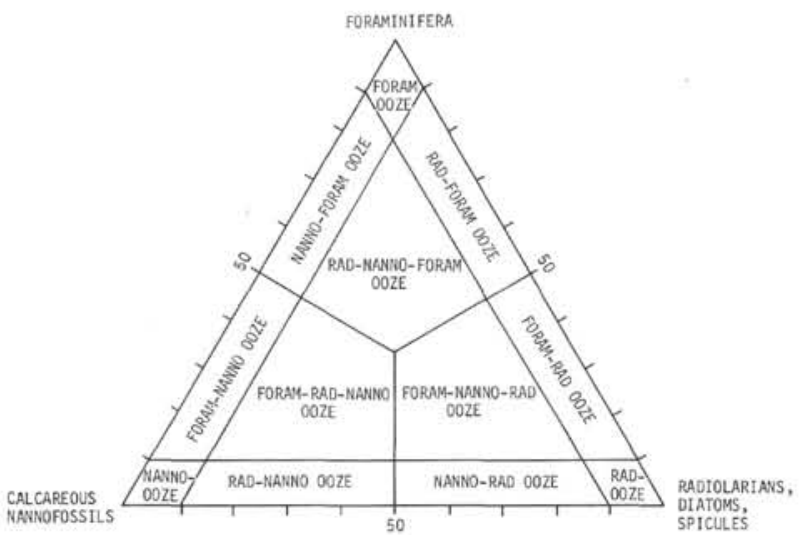

Figure 1. Lithologic classification developed by Leg 9 geologists for oozes and chalks.

\section{FORMATIONS}

The equatorial Pacific deep sea sediments range in age from Upper Eocene through Pleistocene and range from 200 meters thick at Site 80 to 480 meters thick at Site 77. Four distinct lithologic formations are recognized, one of which is divided into two informal mappable units.

\section{LINE ISLANDS OCEANIC FORMATION}

The Line Islands Oceanic Formation was named by Leg 8 scientists after the Line Islands which form a western limit to the equatorial Pacific sedimentary basin. The type section is at Leg 8 Site 70,324 to 388 meters below the sea floor. Sites 60 and 71 through 74 are reference sections. On Leg 9 this formation, which lies directly above basaltic basement, is recognized at Sites $77,78,80,82$ and 83 , a distance of over 4000 kilometers. Its chief characteristics are its dusky brown to pale orange color and stratigraphic position directly above oceanic basement. The brown coloration is due to its variable content of "red clay" which is largely amorphous iron and manganese oxides and lesser amounts of reddish-brown palagonite and clay minerals (Cook and Zemmels, Chapter 11, this volume).

This formation progressively increases in age away from both sides of the East Pacific Rise (Plate 1), from late Miocene at Site 82, near the crest of the East Pacific Rise, to late Eocene at Site 77, our westernmost site. With its relatively uniform thickness of 10 to 25 meters over a 4000 kilometer distance and its stratigraphic position, it serves as a good proximity indicator to basaltic basement.

Sediment types in this formation are dominated by mud-supported textures which consist of calcareous nannofossils with subordinate amounts of foraminifera, radiolarians, amorphous iron and manganese oxides, montmorillonite, and barite. Quartz, kaolin, apatite, clinoptilolite and siderite occur rarely. The mineral tridymite, which was identified petrographically, occurs as minute euhedral crystals lining the interiors of foraminifera tests. The abundance of tridymite is small and was not resolved on any of the X-ray diffractograms. Yellowish-brown montmorillonite occurs in moderate abundance as euhedral laths and as a replacement product of foraminifera. The montmorillonite and tridymite are considered to be of authigenic-hydrothermal origin. In addition, Sites 81 and 82 contain abundant black manganese dendrites. The amount of amorphous iron and manganese oxides range from 1 to 26 per cent by weight of iron oxide $\left(\mathrm{Fe}_{2} \mathrm{O}_{2}\right)$ and 0.5 to 13.0 per cent by weight of manganese oxide $(\mathrm{MnO})$ (Table 3$)$. At Site 77 this formation exhibits a possible overall upward decrease in amorphous iron and manganese and a corresponding color change from dusky brown to a pale orange. (Table 3 , and Chapter 3).

A few types of sedimentary structures are preserved because the formation is moderately to well indurated and was not as disturbed during coring as the overlying formations. The most common type of primary sedimentary structure is laminations with horizontal upper and lower contacts. These laminations consist of different metallic oxide concentrations which give the sediments varying intensities of brown coloration. These laminated metallic oxides indicate a syngenetic origin with the host calcareous chalks. No cross-bedding was observed. At Site 81 these semi-indurated chalks are moderately to intensely brecciated. This brecciation may have formed during intrusion of the underlying basalt. A third type of structure which was found at several sites appears to be partially flattened burrows. These burrows are distinct because the outer rims are a pale yellowish brown in contrast to their dusky brown interiors.

This relatively thin, diachronous, widespread unit is interpreted to represent the initial deposits on or stratigraphically near newly formed oceanic crust. The metallic oxides were possibly formed at ocean floor spreading centers by precipitation from bottom waters enriched in metals by submarine volcanic hydrothermal exhalations. Similar sediments exist in regions of high heat flow on the East Pacific Rise (Bostrom and Peterson, 1966). Progressive spreading of the ocean floor away from hydrothermal areas on rise crests could explain the textural, chemical, spatial, and temporal features of these sediments. (Cook, 1971).

The fact that oceanic basement at these sites is intrusive basalt rather than submarine basalt flows should not be unexpected. Because the basalt does appear to be intrusive, obviously basalt had to intrude some thickness of sediment. Two basic questions emerge. Did these lavas intrude into the base of the sedimentary column and, if so, did the lavas originate along the crest of the East Pacific Rise or did they erupt through the sea floor some unknown distance from the rise-crest? 


\section{TABLE 1}

Rock-Stratigraphic Nomenclature Used on Leg 9, Unit Thicknesses, and their Depths Below the Sea Floor

Site $76-0$ to 27.3 meters

Unit $1-0$ to 9.1 meters

Unit $2-9.1$ to 13.6 meters

Unit $3-13.6$ to 17.9 meters

Unit $4-17.9$ to 21.4 meters

Unit $5-21.4$ to 27.3 meters

Chert

Contact Sharp

Site 77 - Clipperton Oceanic Formation - 0 to 172.5 meters (172.5 meters)

Cyclic Unit -0 to 42.4 meters ( 42.4 meters)

Varicolored Unit -42.4 to 172.5 meters (103.1 meters)

Contact Transitional

Contact Transitional

Marquesas Oceanic Formation - 172.5 to 470.8 meters (298.3 meters)

Gray Unit -172.5 to 252.6 meters ( 80.1 meters)

Brown Unit -252.6 to 280.3 meters ( 27.7 meters)

Gray Unit -280.3 to 408.1 meters ( 127.8 meters)

Brown Unit -408.1 to 426.6 meters ( 18.5 meters)

Gray Unit -426.6 to 470.8 meters ( 44.2 meters)

Contact Sharp

Line Islands Oceanic Formation - 470.8 to 481 meters (10.2 meters)

Basalt

Contact Sharp

Site 78 - Clipperton Oceanic Formation - 0 to 51.7 meters (51.7 meters)

Cyclic Unit -0 to 51.7 meters (51.7 meters)

Marquesas Oceanic Formation - 51.7 to 310.5 meters (258.8 meters)

Brown Unit -51.7 to 101.1 meters (49.4 meters)

Gray Unit - 101.1 to 272.4 meters (171.3 meters)

Brown Unit -272.4 to 310.5 meters ( 38.1 meters)

Line Islands Oceanic Formation -310.5 to 320.3 meters (9.8 meters)

Basalt

Contact Transitional

Contact Sharp

Site 79 - Clipperton Oceanic Formation - 0 to 305 meters (305 meters)

Cyclic Unit - 0 to 45 meters ( 45 meters)

Varicolored Unit -45 to 305 meters ( 260 meters)

Contact Uncored

Contact Uncored

Marquesas Oceanic Formation - 305 to 413.7 meters (108.7 meters)

Brown Unit -305 to 352.6 meters ( 47.6 meters)

Gray Unit - 352.6 to 379.2 meters (26.6 meters)

Brown Unit -379.2 to 413.7 meters ( 34.5 meters)

Basalt

Contact Sharp 


\section{TABLE 1 - Continued}

Site 80 - Clipperton Oceanic Formation - 0 to 90.6 meters ( 90.6 meters)

Varicolored Unit -0 to 90.6 meters ( 90.6 meters)

Marquesas Oceanic Formation - 90.6 to 185 meters ( 94.4 meters)

Brown Unit - 90.6 to 185 meters ( 94.4 meters)

Line Islands Oceanic Formation - 185 to 202.6 meters (17.6 meters)

Basalt

Contact Sharp

Contact Uncored

Contact Uncored

Site 81 - Clipperton Oceanic Formation - 0 to 60 meters (60 meters)

Cyclic Unit -0 to 2.3 meters ( 2.3 meters)

Varicolored Unit -2.3 to 60 meters ( 57.7 meters)

San Blas Oceanic Formation - 60 to 385 meters ( 325 meters)

Line Islands Oceanic Formation - 385 to 409.1 meters ( 24.1 meters)

Basalt

Site 82 - Clipperton Oceanic Formation - 0 to 5.8 meters (5.8 meters)

Cyclic Unit -0 to 5.8 meters ( 5.8 meters)

San Blas Oceanic Formation - 5.8 to 202.6 meters (196.8 meters)

Line Islands Oceanic Formation - 202.6 to 223.0 meters (20.4 meters)

Basalt

Site 83 - Clipperton Oceanic Formation - 0 to 12.6 meters (12.6 meters)

Cyclic Unit -0 to 12.6 meters (12.6 meters)

San Blas Oceanic Formation - 12.6 to 222 meters (209.4 meters)

Unit $1-12.6$ to 49.6 meters ( 37 meters)

Unit $2-49.6$ to 150 meters ( 100.4 meters)

Unit $3-150$ to 222 meters ( 72 meters)

Line Islands Oceanic Formation - 222 to 233 meters (11 meters)

Basalt

Site 84 - San Blas Oceanic Formation - 0 to 253.9 meters (253.9 meters)

Unit $1-0$ to 39.6 meters (39.6 meters)

Unit $2-39.6$ to 87.4 meters ( 47.9 meters)

Unit $3-87.4$ to 128 meters ( 40.6 meters)

Unit $4-128$ to 234.6 meters (106.6 meters)

Unit $5-234.6$ to 253.9 meters (19.3 meters)

Contact Transitional

Contact Sharp

Contact Sharp

Contact Uncored

Contact Uncored

Contact Sharp

. . . . . . . . . . . . . . . . . . .

Basalt

Contact Sharp 


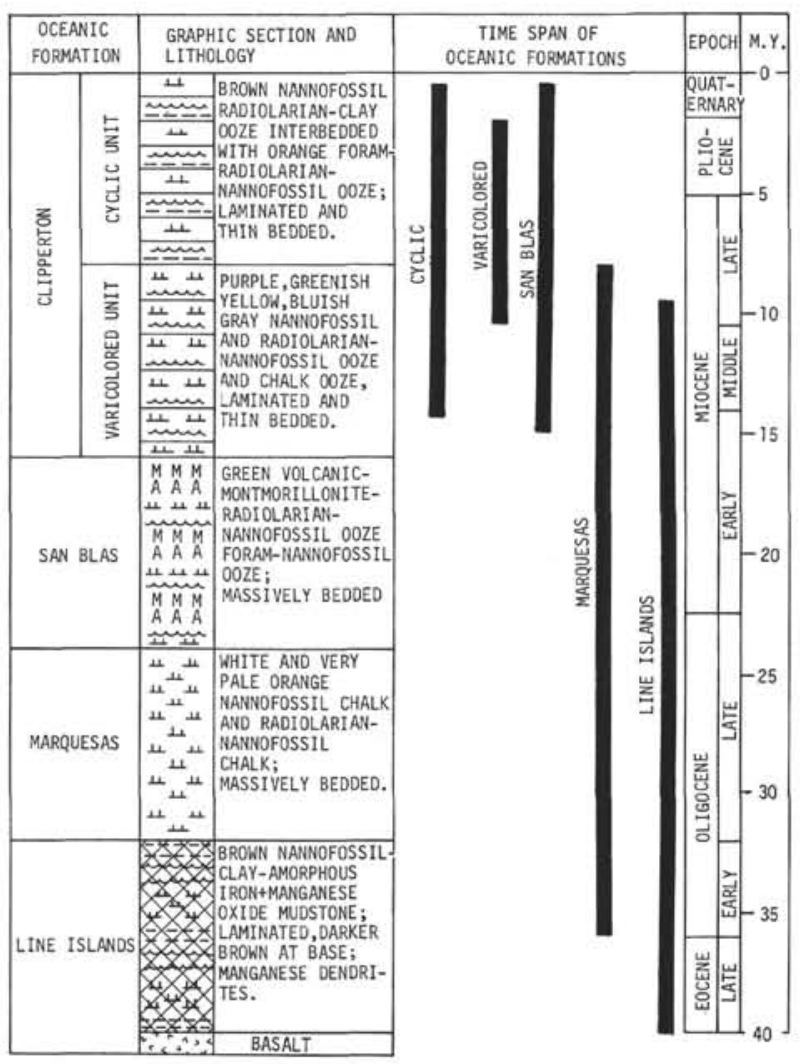

Figure 2. Composite stratigraphic section of equatorial Pacific oceanic formations and their time span. M. $Y .=$ million years.

For intensive and interpretive purposes this basalt is probably stratigraphically close to "true" oceanic flow basement for the following reasons. First, paleontologic ages of the sediment-basalt contact are consistent with sea floor spreading. Second, the calculated sea-floor spreading rates based on the paleontologic ages of sediment basement contact are consistent with acceptable known rates. Third, after Sites 77,78 and 79 were found to have intrusive basement contacts we decided to test our concept that these intrusive contacts were shallow intrusions near "true" oceanic basement. Site 80 was drilled about 320 kilometers south of Site 79 at the same longitude. The sediment-basalt contact at this site was also intrusive and was in the same foraminiferal zone (G. kugleri-Lower Miocene) as Site 79. Although only one test of this type is not conclusive evidence, it does help to support our interpretation. Fourth, the basal stratigraphic unit at six of the eight equatorial sites is always the Line Islands Oceanic Formation. Line Islands sediments as discussed above are very similar to metallic oxide-rich sediments forming today in regions of high heat flow on the East Pacific Rise. These recent metallic-rich sediments are interpreted to represent hydrothermal exhalations genetically associated with new oceanic basement formation at or near ridge crests (Bostrum and Peterson, 1966, 1969; Bostrum et al, 1969).

The evidence strongly supports the interpretation that the basalts did intrude stratigraphically near "true" oceanic flow basement. However, when did they intrude? Without radiometric dates on the basalts we do not know. If the basalts are genetically related to oceanic spreading centers, it seems geologically reasonable that as new oceanic basaltic basement is generated at ridge crests associated intrusive dikes and sills could intrude into the basal few meters of the Line Islands iron-manganese facies. These intrusions would be expected to occur at or near the oceanic ridges. Alternatively, if these basalts erupted through the sea floor at some unknown time and distance from the rise-crest it is reasonable to expect that they would be emplaced at the first major lithologic discontinuity they reached. This discontinuity would be the oceanic basaltic basement - sediment contact. Thus the age of the intrusions remain unknown, although it is highly probable that the basalts are near the base of the sediment column.

The contact with the overlying Marquesas Oceanic Formation at Site 77 is very sharp, whereas, the contact with the overlying Marquesas Formation at Site 78 is transitional over a few centimeters. At Site 82, where the San Blas Oceanic Formation overlies the Line Islands Oceanic Formation, the contact is very sharp. This contact was not cored at other sides. If metallic oxide exhalations were continuous, gradational color contact with the overlying Marquesas and San Blas Oceanic Formations would be expected. Sharp contacts could represent an erosional break, shifting bottomcurrent dispersal patterns, or episodic hydrothermal exhalations.

\section{Marquesas Oceanic Formation}

The Marquesas Oceanic Formation was named by Leg 8 scientists for the Marquesas Islands. The type section is designated at Site 70,45 to 324 meters below the sea floor. Sites 42,69 and 71 through 75 are reference sections. On the basis of stratigraphic position, color and bedding characteristics, the Marquesas Oceanic Formation at Leg 8 is correlated to Sites 77 through 80 . This formation is easily distinguished from the underlying Line Islands Oceanic Formation by its characteristic light grays and very pale orange massive oozes and chalk oozes.

The basal contact of the Marquesas becomes younger in an eastward direction. At Site 77, the basal beds are Lower Oligocene whereas at Site 80,1400 kilometers to the east, the base of the formation is Lower Miocene. Its upper contact varies from Middle to Lower Miocene (Figure 3). The Marquesas is the areally most extensive and thickest formation in the equatorial Pacific. 
TABLE 2

Stratigraphic and Petrographic Summary of Characteristics Used to

Recognize Equatorial Pacific Oceanic Formations, Leg 9, DSDP

\begin{tabular}{|c|c|c|c|c|c|c|c|c|c|}
\hline $\begin{array}{c}\text { Oceanic } \\
\text { Formation \& } \\
\text { Thickness } \\
\text { Range }\end{array}$ & $\begin{array}{c}\text { Dominant } \\
\text { Color(s) }\end{array}$ & Bedding & $\begin{array}{l}\mathrm{CaCO}_{3} \% \\
\text { (approx) }\end{array}$ & $\begin{array}{l}\text { Radiolarian } \\
\% \text { (approx) }\end{array}$ & $\begin{array}{c}\text { Foraminiferal } \\
\% \text { (approx) }\end{array}$ & $\begin{array}{c}\text { Nannofossil } \\
\% \text { (approx) }\end{array}$ & $\begin{array}{l}\text { Pyroclastic } \\
\% \text { (approx) }\end{array}$ & $\begin{array}{c}\text { Clay and Fe-Mn } \\
\text { Oxide Approx. } \\
\text { Weight } \%\end{array}$ & Remarks \\
\hline 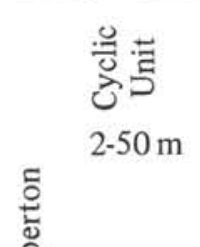 & $\begin{array}{l}\text { Dusky yellowish- } \\
\text { brown, grayish } \\
\text { orange, very } \\
\text { pale orange }\end{array}$ & $\begin{array}{l}\text { Laminated, } \\
5-25 \mathrm{~cm} \text { thick } \\
\text { beds, inter- } \\
\text { bedded colors }\end{array}$ & $25-85$ & $5-50$ & $5-40$ & $30-70$ & $0-5$ & $2-40$ & $\begin{array}{l}\text { Cyclic interbedding of } \\
\text { thin brown and orange } \\
\text { beds characteristic; } \\
\text { common higher natural } \\
\text { gamma count than } \\
\text { underlying units. }\end{array}$ \\
\hline 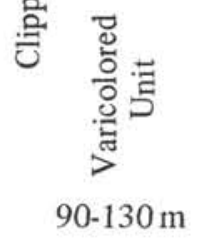 & $\begin{array}{l}\text { Pale purple, } \\
\text { pale greenish } \\
\text { yellow, white, } \\
\text { bluish gray, } \\
\text { very dusky } \\
\text { purple }\end{array}$ & $\begin{array}{l}5-100 \mathrm{~cm} \text { thick } \\
\text { beds, lamin- } \\
\text { ated purple } \\
\text { manganese } \\
\text { layers }\end{array}$ & $35-85$ & $15-50$ & $5-20$ & $30-80$ & $<1$ & $0-5$ & $\begin{array}{l}\text { Pastel colors character- } \\
\text { istic; usually has lower } \\
\mathrm{CaCO}_{3} \% \text {, higher radio- } \\
\text { larian \%, and thinner } \\
\text { beds than Marquesas. }\end{array}$ \\
\hline $\begin{array}{c}\text { San Blas } \\
200-325 \mathrm{~m}\end{array}$ & $\begin{array}{l}\text { Greenish black, } \\
\text { dark greenish } \\
\text { gray, grayish } \\
\text { olive, yellow- } \\
\text { ish gray, very } \\
\text { dusky purple }\end{array}$ & $\begin{array}{l}5-100 \mathrm{~cm} \text { thick } \\
\text { beds, intense } \\
\text { burrowing in } \\
\text { Sites } 83,84\end{array}$ & $10-85$ & $25-50$ & $5-35$ & $30-75$ & $1-25$ & $1-50$ & $\begin{array}{l}\text { Darker green, more } \\
\text { montmorillonite, more } \\
\text { pyroclastics, more } \\
\text { burrowing to west; } \\
\text { higher natural gamma } \\
\text { than Clipperton or } \\
\text { San Blas. }\end{array}$ \\
\hline $\begin{array}{l}\text { Marquesas } \\
95-300 \mathrm{~m}\end{array}$ & $\begin{array}{l}\text { White, bluish } \\
\text { white, very } \\
\text { pale orange, } \\
\text { light gray }\end{array}$ & $\begin{array}{l}25-200 \mathrm{~cm} \\
\text { thick beds, } \\
\text { rare lamina- } \\
\text { tions }\end{array}$ & $45-99$ & $1-40$ & $5-50$ & $40-99$ & $<1$ & $<1$ & $\begin{array}{l}\text { Usually has higher } \\
\mathrm{CaCO}_{3} \% \text {, lower radio- } \\
\text { larian \%, and thicker } \\
\text { beds than Clipperton }\end{array}$ \\
\hline $\begin{array}{l}\text { Line Islands } \\
10-25 \mathrm{~m}\end{array}$ & $\begin{array}{l}\text { Dusky brown, } \\
\text { pale yellowish } \\
\text { brown, pale } \\
\text { orange }\end{array}$ & $\begin{array}{l}\text { Laminations, } \\
\text { darker brown } \\
\text { towards base, } \\
\text { flattened bur- } \\
\text { rows, manga- } \\
\text { nese dendrites }\end{array}$ & $35-99$ & $0-40$ & $0-50$ & $40-80$ & $<1$ & $1-50$ & $\begin{array}{l}\text { Commonly progressive } \\
\text { darker brown towards } \\
\text { base; stratigraphically } \\
\text { on basalt. }\end{array}$ \\
\hline
\end{tabular}


In an east-west direction it extends at least from Site 69 to Site 80 , a distance of 3000 kilometers, and from Site 70 to 75 , a north-south distance of 2000 kilometers. An unpublished isopach map of Leg 8 and 9 data shows that the Marquesas attains a maximum thickness of 355 meters in the vicinity of the present central equatorial region and pinches out away from this area. At Site 77 it is divided into five informal units based essentially on color differences. Here it consists of gray and very pale orange inter-bedded units which range from about 20 to 125 meters in thickness (Table 1). As the Marquesas Oceanic Formation is traced eastward, the gray units apparently pinch out and are replaced by pale orange units. Further eastward, between Sites 80 and 81 and 79 and 81 , the Marquesas Oceanic Formation interfingers with the San Blas Oceanic Formation.

Calcium-carbonate content in the Marquesas is usually more than 99 per cent but ranges from 85 to 99 per cent. This high calcium-carbonate content is a characteristic feature of the Marquesas and is higher than the underlying Line Islands Oceanic Formation or the overlying Clipperton Oceanic Formation. A high calcium-carbonate content in the Marquesas reflects the very high calcareous nannofossil and low radiolarian content. This is in contrast to the overlying Clipperton Oceanic Formation which has a higher percentage of radiolarians. The dominant mineral in the Marquesas is calcite contributed by calcareous nannofossils. Other minerals which occur in minor amounts include quartz, $\mathrm{K}$-feldspar, plagioclase, kaolin, mica, montmorillonite, barite, siderite, clinoptilolite, magnetite, dolomite, and geothite. These minerals are discussed elsewhere in this volume (Cook and Zemmels, Chapter 11).

The gray units of the Marquesas Formation are characteristically massive with no apparent laminations. Beds in the gray units range from 50 to 150 centimeters in thickness. The brown or light orange units are characterized by orange colors that occur in 25 to 150-centimeter-thick beds, again with no obvious laminations. Many of the yellowish-brown beds are burrowed, which gives them a slightly mottled appearance.

Where cored, the contact with the overlying Clipperton Oceanic Formation is transitional over several centimeters.

\section{San Blas Oceanic Formation}

The San Blas Oceanic Formation is here named for the San Blas Islands off the west coast of Panama.

This formation, which was first cored at Site 81 , can be lithologically correlated to Sites 82,83 and 84 . It was continuously cored at Site 84 , and this site is designated as its type locality. Sites 81 through 83 are reference sections. The San Blas is easily distinguished from the other formations by its green colors which usually persist over long stratigraphic intervals with no obvious laminations. Other characteristic features are occasional dusky purple, manganese-rich streaks and moderately to intensely burrowed zones with grayishorange sediments mixed in with the green sediments.

The San Blas is the dominant formation in the eastern part of equatorial Pacific and extends across both sides of the East Pacific Rise for a distance of at least 3200 kilometers. It is one of the thickest formations in the equatorial Pacific, with a minimum thickness of at least 250 meters at Site 84 . It may be as thick as 325 meters at Site 81 .

This formation is also diachronous, with its basal contact becoming younger as the crest of the East Pacific Rise is approached from both sides. West of the Rise its basal contact ranges from Lower to Upper Miocene. East of the Rise the basal beds range from Middle to Upper Miocene. West of the Rise its upper contact is near the Miocene-Pliocene boundary while east of the Rise it extends into the Pleistocene.

Common lithologic types in the San Blas Oceanic Formation include light bluish-gray and medium bluishgray radiolarian-calcareous nannofossil chalk with some managanese which coats radiolarians, and greenish-gray to dark greenish-gray montmorillonite foraminiferalradiolarian-calcareous nannofossil ooze with volcanic shards, pumice fragments, pyroxenes and amphiboles. The coloration in the San Blas is due to abundant green montmorillonite (Cook and Zemmels, Chapter 11, this volume), which has formed from the devitrification of pyroclastic glass shards and pumice fragments. The calcium-carbonate content ranges from a high of 90 per cent at Site 81 to a low of about 10 per cent in parts of Site 84 (Figure 4).

This eastward decrease in its calcium-carbonate content is inversely proportion to its degree of green coloration. The eastermost Site 84 contains the highest percentage of volcanic constituents and montmorillonite and has the lowest calcium-carbonate content. To the west, the formation becomes a lighter green, becomes more calcarious, and decreases correspondingly in montmorillonite and volcanic constituents. The major constituents in the formation includes calcite, opaline silica, volcanic material, and green montmorillonite. Numerout other minerals that occur in minor amounts include: quartz, K-feldspar, plagioclase, kaoline, chlorite, mica, barite, clinoptilolite, pyrite, dolomite and siderite. Between Sites 80 and 81, and 79 and 81, the Marquesas interfingers with the San Blas Oceanic Formation.

Primary sedimentary structures consist of 1 to 2 millimeter-thick parallel laminations and burrowed intervals. Most of the formation is not laminated occurring in 5 millimeter- to 20 centimeter-thick beds with 
fairly sharp parallel contacts delineated by subtle or marked color changes. Both aeolian and pelagic sediments characterize the San Blas. These aeolian volcanic materials most likely originated on the nearby North or South American continents, and this is probably responsible for the eastward increase in volcanic constituents.

At Sites 82 and 83 , where the San Blas is overlain by the Clipperton Oceanic Formation, the contact is gradational over about two meters. At Site 82 , where the contact between the San Blas and Line Islands Oceanic Formations was cored, the contact is very sharp with no gradation. At Sites 81 and 83 , the contact with the overlying Clipperton was not cored.

\section{Clipperton Oceanic Formation}

The Clipperton Oceanic Formation was named by Leg 8 scientists for the Clipperton Fracture Zone, which is situated south of the designated type section (Site 70, 0 to 45 meters). Sites 69 and 71 through 74 are reference sections. The Clipperton Oceanic Formation can be recognized at Sites 77 through 83 . It is divided into an upper brown and orange cyclic unit and an underlying gray, green, and purple varicolored unit.

\section{Varicolored Unit}

The varicolored unit is characterized by interbedded and laminated siliceous and calcareous oozes that display brilliant shades of purples and greens. These colors serve to easily distinguish it from the overlying and underlying stratigraphic units. Contacts between the different colors are sharp and occasionally one can see one millimeter-thick laminations in the purple and green beds. The purple color is probably due to some form of manganese that coats the surfaces of radiolarians and also occurs as grains disseminated throughout the beds.

The varicolored unit of the Clipperton Oceanic Formation is diachronous and generally becomes younger to the east (Plate 1). At Site 77 its lower contact is Middle Miocene, while at Site 82 its lower contact is probably late Pliocene. Its upper contact at Site 77 is late Pliocene, whereas, at Site 81, 2000 kilometers to the east, the top of the formation is Pleistocene. The varicolored unit has a variable thickness ranging from less than 90 meters at Site 80 to more than 285 meters at Site 79. Apparently it reaches its maximum thickness in the vicinity of Site 79 and interfingers with other formations in all directions away from this area.

It is distinguished from the underlying Marquesas Oceanic Formation by its variegated pastel shades and lower carbonate content. In the varicolored unit of the Clipperton, the percentage of radiolarians and foraminifera is generally higher than in the Marquesas Oceanic Formation. Quartz, K-feldspar, plagioclase, kaolin, mica, montmorillonite, barite, siderite, and apatite occur in minor amounts in the 20 -micron fraction.

The upper contact of the varicolored unit is gradational with the cyclic unit over several tens of centimeters.

\section{Cyclic Unit}

This unit is lithologically and stratigraphically correlative with the cyclic unit of the Leg 8 Clipperton Oceanic Formation. The best example of this unit is at Site 82 . It is very widespread, as it is recognized at Sites 77, 78, 79, 81, 82 and 83 (Plate 1), and at Sites 69 through 74 of Leg 8, a total distance of almost 6000 kilometers. This cyclic unit is one of the most distinctive lithologies in the equatorial Pacific because of its thin-bedded, cyclic colors and lithology. It is characterized by the repeated interbedding of light to dusky brown siliceous oozes and orange calcareous oozes. Beds range from about one to 25 centimeters in thickness and exhibit horizontal, sharp contacts.

The brown beds are rich in armorphous iron oxides and commonly have a higher radiolarian content than the pale orange interbeds. In addition, the dark brown beds sometimes have pumice fragments in various stages of alteration. Within the dark brown and pale orange beds minor amounts of quartz, K-feldspar, plagioclase, kaoline, mica, montmorillonite, barite, cristobolite, phillipsite, clinoptilolite and magnetite occur.

In an east-west direction along the equator, the cyclic unit tends to be relatively uniform in age, ranging from Upper Pliocene to Pleistocene (Plate 1), whereas in a northerly or southerly direction away from the equator it becomes progressively older. For example, at Site 77 it is Upper Pliocene and Pleistocene in age, whereas at Site 78, 1000 kilometers to the north it is Middle Miocene in age. This increase in age away from the equator was also found in the cyclic unit of Leg 8 .

The origin of these cyclic, thin bedded, dusky brown and very pale orange sediments is unknown. Any model for its origin must take into account the time transgressive nature of this unit, the high content of amorphous iron in the dusky brown beds, the common high content of radiolarians in the dusky brown beds, a larger percentage of volcanic constituents in the dusky brown beds than the pale orange beds, the upward decrease in amorphous iron oxides within some individual dusky brown beds, the sharp contacts between the cyclic beds, and sea floor spreading moving the position of the sediments through time. A high percentage of volcanic materials in the dusky brown beds suggests cyclic volcanic events; however, the diachronous nature of the unit, particularly the mirror image age relationship across the equator, makes this unlikely. Another interpretation could be that the greater percentages of clay, amorphous iron oxides, and radiolar- 
ians in the dusky brown sediments reflect a cyclic dissolution of calcareous fossils and a concentration of the noncalcareous constituents. However, this interpretation is not adequately supported by the present data either. A mass balance between the very pale orange, calcareous beds and the dusky brown carbonate-poor beds does not seem to support a simple dissolution and concentration mechanism. Almost all of the orange beds have an extremely low percentage of noncalcareous constituents; there is probably less than one or two per cent, and in most cases virtually none. Thus in order to dissolve enough of the orange calciumcarbonate-rich sediments to accumulate multiple 10 to 20 centimeter thick beds of noncalcareous sediment should require more sediments than could conceivably have been deposited during this time interval. For example, to produce just one 15 -centimeter thick bed with 65 per cent by volume of clay by dissolving calcareous oozes with 1 per cent clay would require dissolution of about 10 meters of calcareous ooze. Furthermore, simple dissolution does not adequately explain the fact that some of the brown beds show an upward decrease in clay and amorphous iron oxide.

Arrhrenius (1952) has interpreted similar cyclic sediments in the equatorial Pacific to be a product of alternating warm and cold climatic cycles (Hays et al., Chapter 21, this volume). However, climatic cycles alone cannot adequately explain some of the most distinctive features of the Clipperton's cyclic unit namely, the diachronous nature of the cyclic unit and the decrease upward in reddish-brown amorphous iron oxides within some of the individual dusky brown "red clay" beds. The climatic cycle theory postulates that the white and very pale orange calcareous-rich beds form during cold cycles and the brown siliceous-rich beds form during warm cycles. If this occurs one might expect the upward change from white calcareous-rich beds (cold cycle) to dark brown siliceous-rich "red clay" beds (warm cycle) to be gradational and to perhaps exhibit an upward darkening of the brown coloration and an upward increase in siliceous material; however, most of the contacts between the white and brown beds are sharp and the brown beds become lighter brown upward and contain less "red clay" upward.

\section{CONCLUSIONS}

1. The equatorial Pacific sediments can be divided into at least four lithologically distinct oceanic formations. Principal criteria found useful for defining and lithologically correlating these units are color differences, bedding characteristics and stratigraphic position.

2. Major sedimentary regimes in the equatorial Pacific were areally and temporally persistent as suggested by the fact that individual formations can be traced over thousands of kilometers.
3. Oceanic basalt was reached at all of the eight equatorial sites. At each site the contact between basaltic basement and the overlying Line Islands Formation is probably intrusive. This is evidenced by sediment xenoliths in the basalt, chilled glassy margins at the basalt contact, and baking of the overlying Line Islands sediments. Stratigraphic position of the basalts and the ages of the overlying sediments suggest that these basalts represent sills and/or dikes which probably intruded stratigraphically near true basement. The basalts could either have originated along the crest of the East Pacific Rise and be genetically related to active spreading centers or they could have erupted through the sea floor at some unknown time and distance from the rise-crest.

4. The wide-spread diachronous iron-and manganeserich Line Islands Oceanic Formation which occurs directly above basalt has important genetic implications. These metallic oxides probably represent initial hydrothermal exhalations that occur on or near newly formed oceanic ridge basalt. As new crustal material forms, this basal iron-manganese facies moves away from the oceanic ridge. In this way continuous or nearly continuous hydrothermal emanations coupled with sea floor spreading produce a diachronous, basal iron-manganese-rich unit. If this interpretation is correct the presence of this formation which systematically transgresses time away from both sides of the East Pacific Rise is further support for sea floor spreading.

5. Volcanic activity, possibly in the Central and South America area, was continuous at least from Lower Miocene into the Pleistocene. This is reflected by the pyroclastic material in the San Blas Oceanic Formation which ranges from a high of 90 per cent by weight in the eastern sites to less than 10 per cent in the western most San Blas cores. West of Site 81 pelagic biotic contributions form the major lithologic elements.

6. These formations are not isochronous. Rather they transgress time and probably reflect sea floor spreading bringing sites into major sedimentation regimes.

7. Unpublished isopachs of the Marquesas Oceanic Formation and varicolored unit of the Clipperton Oceanic Formation suggest that maximum sedimentation rates took place near the equator and decreased away from the equator both north and south.

Sedimentation rates in the pelagic sediments range from less than $2 \mathrm{~m} / \mathrm{m} . \mathrm{y}$. to more than $20 \mathrm{~m} / \mathrm{m}$.y. The higher rates of pelagic sedimentation occurs underneath the high productivity belt in the equatorial Pacific. To the west the San Blas Oceanic Formation, which is a combination of pelagic and eolian derived volcanic constituents, attains a sedimentation rate of $45 \mathrm{~m} / \mathrm{m} . \mathrm{y}$. This extremely high deep-sea sedimentation rate is probably due mainly to eolian pyroclastic contributions. 
TABLE 3

Atomic Absorption Analyses of the Line Islands Oceanic Formation,

Leg 9, Deep Sea Drilling Project

\begin{tabular}{|c|c|c|c|c|c|c|c|c|c|c|c|c|c|c|c|c|}
\hline \multirow[b]{2}{*}{ Site } & \multirow{2}{*}{$\begin{array}{l}\text { Sample } \\
\text { Hole-Core-Section- } \\
\mathrm{cm} \text { from top of sec. }\end{array}$} & \multicolumn{8}{|c|}{$\%$ Oxide of Element } & \multicolumn{7}{|c|}{ ppm of Element } \\
\hline & & $\mathrm{Na}_{2} \mathrm{O}$ & $\mathrm{K}_{2} \mathrm{O}$ & $\mathrm{MgO}$ & $\mathrm{CaO}$ & $\mathrm{Al}_{2} \mathrm{O}_{3}$ & $\mathrm{Fe}_{2} \mathrm{O}_{3}$ & $\mathrm{MnO}$ & $\mathrm{P}_{2} \mathrm{O}_{5}$ & $\mathrm{Ba}$ & Co & $\mathrm{Cu}$ & $\mathrm{Ni}$ & $\mathrm{Sr}$ & $\mathrm{Zn}$ & $\mathrm{V}$ \\
\hline \multirow{6}{*}{77} & $77 \mathrm{~B}-52-1-80-84$ & 0.26 & 0.40 & 1.01 & 13.58 & 0.84 & 1.93 & 0.41 & 0.08 & 1500 & 0 & 580 & 0 & 370 & 140 & 0 \\
\hline & 77B-52-1-100-102 & 0.20 & 0.44 & 2.45 & 40.89 & 0.93 & 2.80 & 0.60 & 0.07 & 2000 & 0 & 280 & 90 & 510 & 140 & 0 \\
\hline & 77B-52-1-139-141 & 0.33 & 1.69 & 4.88 & 9.87 & 4.08 & 17.73 & 4.28 & 0.12 & 0 & 680 & 650 & 390 & 510 & 360 & 230 \\
\hline & 77B-52-2-60-62 & 0.41 & 1.45 & 4.69 & 8.06 & 2.66 & 22.27 & 6.02 & 0.09 & 0 & 780 & 0 & 450 & 520 & 420 & 230 \\
\hline & 77B-52-2-100-102 & 0.24 & 0.75 & 3.11 & 25.71 & 1.63 & 11.39 & 2.48 & 0.11 & 3900 & 0 & 550 & 160 & 860 & 320 & 0 \\
\hline & 77B-53-1-97-98 & 0.18 & 0.53 & 2.42 & 32.38 & 0.97 & 11.03 & 1.61 & 0.11 & 1800 & 0 & 530 & 120 & 880 & 260 & 0 \\
\hline 79 & $79-16-3-80-82$ & 0.00 & 0.06 & 0.66 & 47.48 & 0.18 & 1.37 & 0.45 & 0.09 & 0 & 0 & 190 & 0 & 920 & 90 & 0 \\
\hline 80 & $80-5-3-80-82$ & 0.07 & 0.23 & 1.46 & 47.20 & 0.47 & 4.99 & 1.67 & 0.11 & 0 & 0 & 330 & 0 & 750 & 130 & 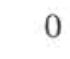 \\
\hline \multirow{4}{*}{81} & $81-6-3-5-7$ & 0.14 & 0.21 & 5.72 & 37.81 & 0.39 & 4.88 & 0.97 & 0.05 & 0 & 0 & 10 & 160 & 580 & 140 & 0 \\
\hline & $81-6-3-140-142$ & 0.12 & 0.08 & 2.92 & 42.62 & 0.12 & 2.99 & 0.81 & 0.08 & 600 & 0 & 450 & 50 & 700 & 130 & 0 \\
\hline & $81-7-1-62-64$ & 0.63 & 0.48 & 4.55 & 30.84 & 3.52 & 4.50 & 5.89 & 0.11 & 0 & 480 & 330 & 460 & 590 & 240 & 0 \\
\hline & $81-7-1-74-75$ & 0.48 & 0.35 & 3.72 & 35.87 & 2.57 & 4.49 & 1.76 & 0.10 & 0 & 0 & 330 & 180 & 560 & 200 & 0 \\
\hline \multirow{2}{*}{82} & $82-6-6-100-103$ & 0.22 & 0.55 & 3.65 & 27.50 & 0.91 & 9.49 & 2.83 & 0.13 & 2100 & 480 & 470 & 120 & 580 & 190 & 0 \\
\hline & $82-6-6-150$ & 0.03 & 0.13 & 1.24 & 21.91 & 0.05 & 2.11 & 0.69 & 0.07 & 0 & 0 & 170 & 60 & 400 & 130 & 0 \\
\hline 83 & $83-8-1$ & 0.09 & 0.16 & 3.96 & 33.36 & 1.26 & 5.10 & 1.13 & 0.13 & 0 & 0 & 0 & 160 & 520 & 280 & 0 \\
\hline
\end{tabular}

$\mathrm{Pb}$ : All samples contain less than $20 \mathrm{ppm}$. Dr. Fetter, Institute of Geophysics and Planetary Physics, University of California, Riverside performed the analyses (see Appendix, this chapter, for analytical procedures). 


\section{REFERENCES}

Andrews, J., and Hsu, K., Jinghwa, 1970. Note 38-a recommendation to the American Commission on Stratigraphic Nomencalture concerning nomenclatural problems of submarine formations. Bull. Am. Assoc. Petrol. Geol. 54, 1746.

1961. Code of Stratigraphic Nomenclature. Bull. Am. Assoc. Petrol. Geol. 45, 645.

Arrhenius, G., 1952. Sediment cores from the East Pacific. Repts. Swedish Deep-Sea Expedition. 5, 85 p. (Goteborg).

Bostrum, K. and Peterson, M. N. A., 1966. Precipitates from hydrothermal exhalations on the East Pacific Rise. Econ. Geol. 61, 1258.

, 1969. The origin of aluminum-poor ferromanganoan sediments in areas of high heat flow on the East Pacific Rise. Marine Geol. 7, 427.

Bostrom, K., Peterson, M. N. A., Joensuu, O. and Fisher, D. E., 1969. Aluminum-poor ferromanganoan sediments on active- oceanic ridges. J. Geophys. Res. 74, 3261 .

Cook, H. E., 1971. Iron and manganese rich sediments overlying oceanic basaltic basement, equatorial $\mathrm{Pa}-$ cific, Leg 9, D.S.D.P. (abst) Geol. Soc. Am. Annual Meeting, Washington, D. C.

Sutton et al., 1971. Initial Reports of the Deep Sea Drilling Project. Volume VIII. Washington (U. S. Government Printing Office).

\section{APPENDIX}

Analytical Techniques used in the Chemical Analyses of the Line Islands' Oceanic Formation Sediments

Samples were placed in a Waring blendor with about 100 milliliters of deionized double distilled water and ground for two minutes at high speed. This suspension was centrifuged for 10 minutes at $1800 \mathrm{rpm}$ and the supernatant decanted. The sample was washed with 50 milliliters of distilled water, centrifuged again, and the wash water removed by decantation.

The washed samples were dried in polypropylene cups for 20 hours or more at $80^{\circ} \mathrm{C}$ in a circulating air oven. The dry samples were removed from the cups, ground in an agate mortar, and stored in labeled envelopes.

Approximately 0.5-gram samples were weighed into the Teflon cup of a Parr digestion bomb. Several drops of distilled water were added to wet the sample and 7 to 8 milliliters of concentrated hydrofluoric acid was added. The bomb was assembled and heated for at least one hour at $140^{\circ}$.
Upon cooling, the contents of the Teflon cup were poured into a plastic cup contianing 60 milliliters of saturated boric acid solution. A 10-milliliter quantity of concentrated hydrochloric acid was then added, and the cups were capped and heated on a steam bath until a clear solution was obtained. The solutions were cooled to room temperature, diluted to 100 milliliters in a volumetric flask, and stored in plastic bottles.

For certain elements, sample solutions were diluted with a Dilutrol Automatic Dilutor. In the case of alkali and alkaline earth elements, samples were diluted $1: 25$. Cesium was automatically added with the diluent to give a $1000 \mathrm{ppm}$ cesium concentration for ionization suppression.

In those samples which were high in calcium carbonate, a dilution ratio of $1: 100$ was required.

Samples with a high iron concentration required a dilution of 1:5. For all other elements the original solution was used. Titanium was not analyzed because of interference resulting from the attack of the acidic sample solutions on the titanium-nitrous-oxide burner head.

All atomic absorption analyses were conducted on a Perkin-Elmer Model 290 atomic absorption spectrophotometer with a Beckman strip chart recorder. Either an air/acetylene or a nitrous oxide/acetylene flame was used as approprite. Data reduction was performed by a special atomic absorption program on a PDP-8 computer.

Phosphorus was analyzed by an indirect method. The phosphate ion was allowed to react with a solution of ammonium molybdate in a citrate buffer. The resultant phosphomolybdate complex was extracted into n-octyl alcohol. After centrifugation to clarify the solution, the alcohol was analyzed by atomic absorption for molybdenum response. Appropriate standards were prepared from phosphate solutions of known concentration.

The analytical data for $\mathrm{SiO}_{2}$ is not reported. Comparison of results from the analysis of U.S.G.S. standards W-1 and G-2 against published values for these rocks, show a wide variation which indicates an analytical problem which existed when the samples were run. The difficulty may be attributed to either deterioration of standards or to the beginning of the instrumental breakdown which was detected later in the week. This problem does not affect the accuracy of the other data. 